\title{
26. PALEOGENE CALCAREOUS NANNOFOSSILS FROM THE KERGUELEN PLATEAU, LEG 1201
}

\author{
Marie-Pierre Aubry²
}

\begin{abstract}
Calcareous nannofossils are abundant in the Paleogene sediments recovered during Ocean Drilling Program Leg 120. Although no continuous Paleogene section was obtained, Sites 747 through 751 complemented each other so as to provide a virtually complete composite stratigraphic section. The calcareous nannofossil biostratigraphy at Sites 747,748 , and 749 is discussed. Correlation of calcareous nannofossil biozones and magnetozones at these sites suggests some diachrony with low-latitude areas, as well as on a regional basis. Changes in calcareous nannofossil diversity throughout the Paleogene are analyzed and interpreted as reflecting major paleoclimatic events.
\end{abstract}

\section{INTRODUCTION}

Ocean Drilling Program (ODP) Leg 120 drilled central and southern sites on the Kerguelen Plateau, completing the latitudinal transect initiated during Leg 119 between Kerguelen Island (49 $\mathrm{S}$ ) and Prydz Bay, Antarctica (67 $\left.{ }^{\circ} \mathrm{S}\right)$ (Fig. 1). The purpose of the transect was to study the Late Cretaceous to Holocene paleoceanographic history of the region, the origin and tectonic history of the Kerguelen Plateau, the nature and the age of the Kerguelen Plateau basement, and the late Mesozoic rifting history of East Antarctica. As the last of a series of high southern latitude legs, Leg 120 also helped to improve our knowledge of the sedimentary record in the Southern Ocean.

We drilled Sites 747-751 on Leg 120 and recovered thick sections of Neogene, Paleogene, and Upper Cretaceous sediments above basaltic basement (Fig. 2). Stratigraphic resolution was achieved through different means for different stratigraphic intervals. Stratigraphic subdivision of Neogene sediments was achieved through integration of magnetostratigraphy (Heider et al., this volume, Chapter 15; Inokuchi, this volume) with planktonic foraminifer (Berggren, this volume), radiolarian (Lazarus, this volume), and diatom (Harwood, this volume) stratigraphies. The magnetostratigraphy (Heider et al., this volume, Chapter 15; Inokuchi, this volume) complemented calcareous nannofossil and planktonic foraminifer (Berggren, this volume) stratigraphies for Oligocene sediments, whereas these two paleontologic groups constituted the primary stratigraphic means for the upper Eocene through Upper Cretaceous sediments recovered during the leg (Berggren, this volume; Quilty, this volume; Watkins, this volume).

Because of the extremely low diversity, calcareous nannofossils contributed very little information toward the stratigraphy of the Neogene series recovered during Leg 120 (see Schlich, Wise, et al., 1989, pp. 89-156, 157-235, and 339373). Data useful for the stratigraphy of the Neogene sediments recovered during Leg 120 are discussed in papers dealing with the significance of fluctuations in abundance between the two taxa Coccolithus pelagicus and species of the

\footnotetext{
${ }^{1}$ Wise, S. W., Jr., Schlich, R., et al., 1992. Proc. ODP, Sci. Results, 120: College Station, TX (Ocean Drilling Program).

${ }^{2}$ Centre de Paléontologie Stratigraphique et Paléoécologie (URA 11), Université Claude Bernard, 27-43 Blvd. du 11 Novembre, 69622 Villeurbanne, Cedex, France, and Woods Hole Oceanographic Institution, Woods Hole, MA 02543, U.S.A.
}

genus Reticulofenestra throughout the Miocene of the Kerguelen Plateau (Beaufort and Aubry, this volume; Beaufort, in press).

On the other hand, calcareous nannofossils provided critical stratigraphic information for the Paleogene series. In this paper, the distribution of the calcareous nannofossils in the Paleogene sediments recovered during Leg 120 is given. Diversity changes throughout the Paleogene are described based on semiquantitative data, and their implications are briefly discussed. The Cretaceous/Paleogene contact was recovered at Site 750 (Schlich, Wise, et al., 1989, pp. 277-337). The changes that the calcareous nannofossil assemblages exhibit at this contact are described separately (Ehrendorfer and Aubry, this volume).

\section{METHODS AND PROCEDURES}

Smear slides were prepared for all samples and analyzed by light microscopy at magnification $\times 1200$ to identify large and small taxa for diversity studies. Because Paleogene assemblages are generally dominated by one or two species, the abundance estimates of other taxa are rather subjective. To minimize this subjective effect and because the same assemblages are the object of an independent quantitative analysis (Aubry, in progress), only four categories are used to describe the abundance of taxa. In the accompanying range charts (Tables 1-5), the category "abundant" (A) refers to the dominant species (more than $50 \%$ of an assemblage) and "common" (C) refers to the next most abundant taxa (between $10 \%$ and $50 \%$ ). The category designated as "few" (F) constitutes $<10 \%$ of an assemblage, whereas "rare" (R) are taxa in which only one to a few specimens were observed while scanning the slide. Dots mean that a taxon is likely to occur but cannot be differentiated from a closely related species because of the poor preservation. This is the case for Chiasmolithus oamaruensis in upper Oligocene oozes, which cannot be differentiated easily from $C$. altus because the central structure of most placoliths of this genus is missing. Discrete taxa regarded as reworked are marked with an X, which provides no significance as to the frequency of the reworked taxon. When massive mixing occurs, as in the Paleocene-lower Eocene sections recovered from Holes 747A and $747 \mathrm{~B}$, reworked taxon frequency (as described above) is given. Because the abundance of taxa varies broadly between consecutive samples, particularly in the Oligocene oozes, continuous stratigraphic occurrence rather than frequency was the criterion used to delineate highest $(\mathrm{HO})$ or lowest (LO) occurrences. 

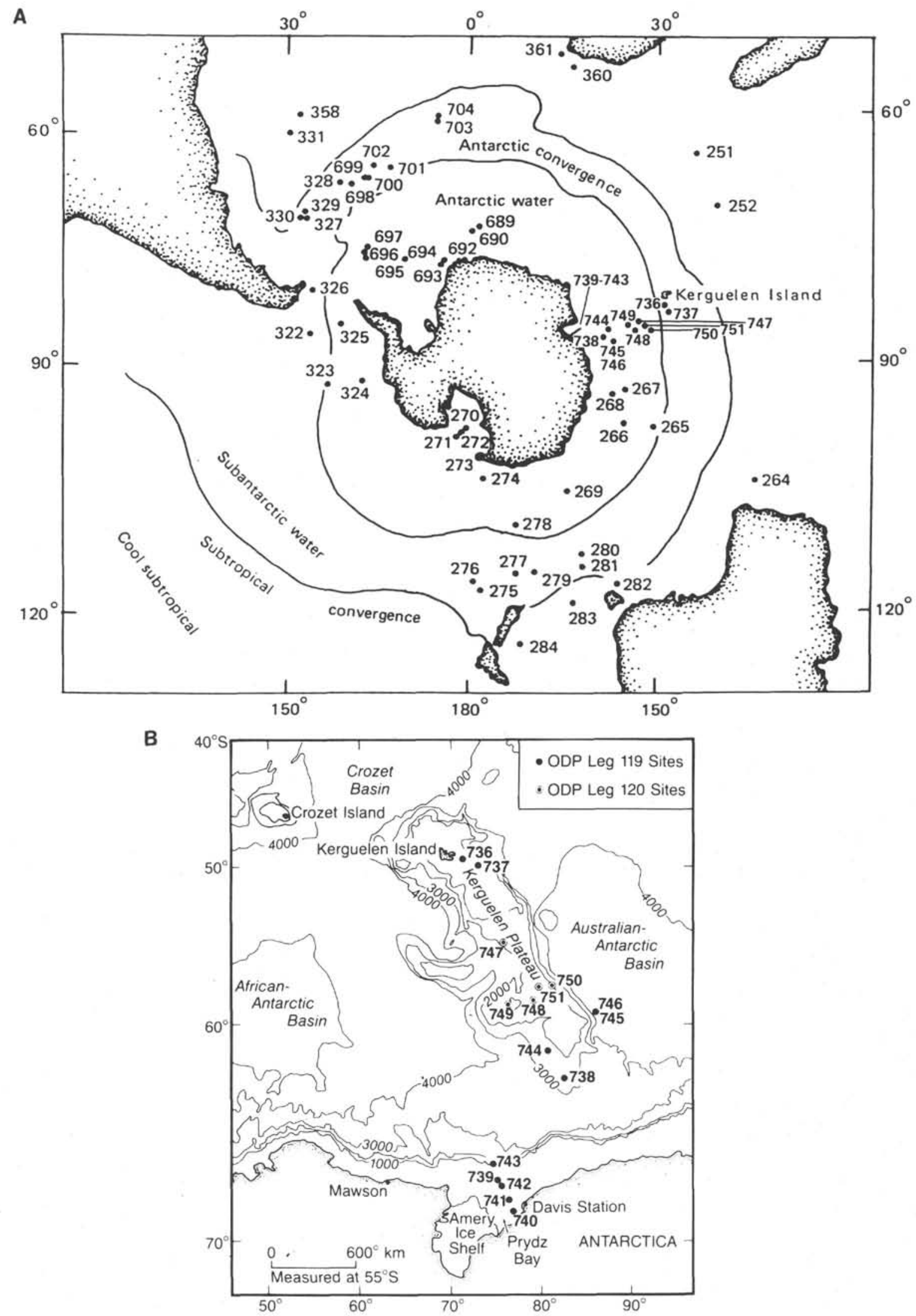

Figure 1. A. Map showing present-day location of surface-water masses of the Southern Ocean (from Kennett, 1978). Numbers indicate DSDP and ODP sites (from Schlich, Wise, et al., 1989, pp. 7-23, fig. 2). Contour intervals in meters. B. Bathymetric chart of the Kerguelen Plateau with the location of Leg 120 sites and previously drilled Leg 119 sites (from Schlich, Wise, et al., 1989, pp. 73-85). 


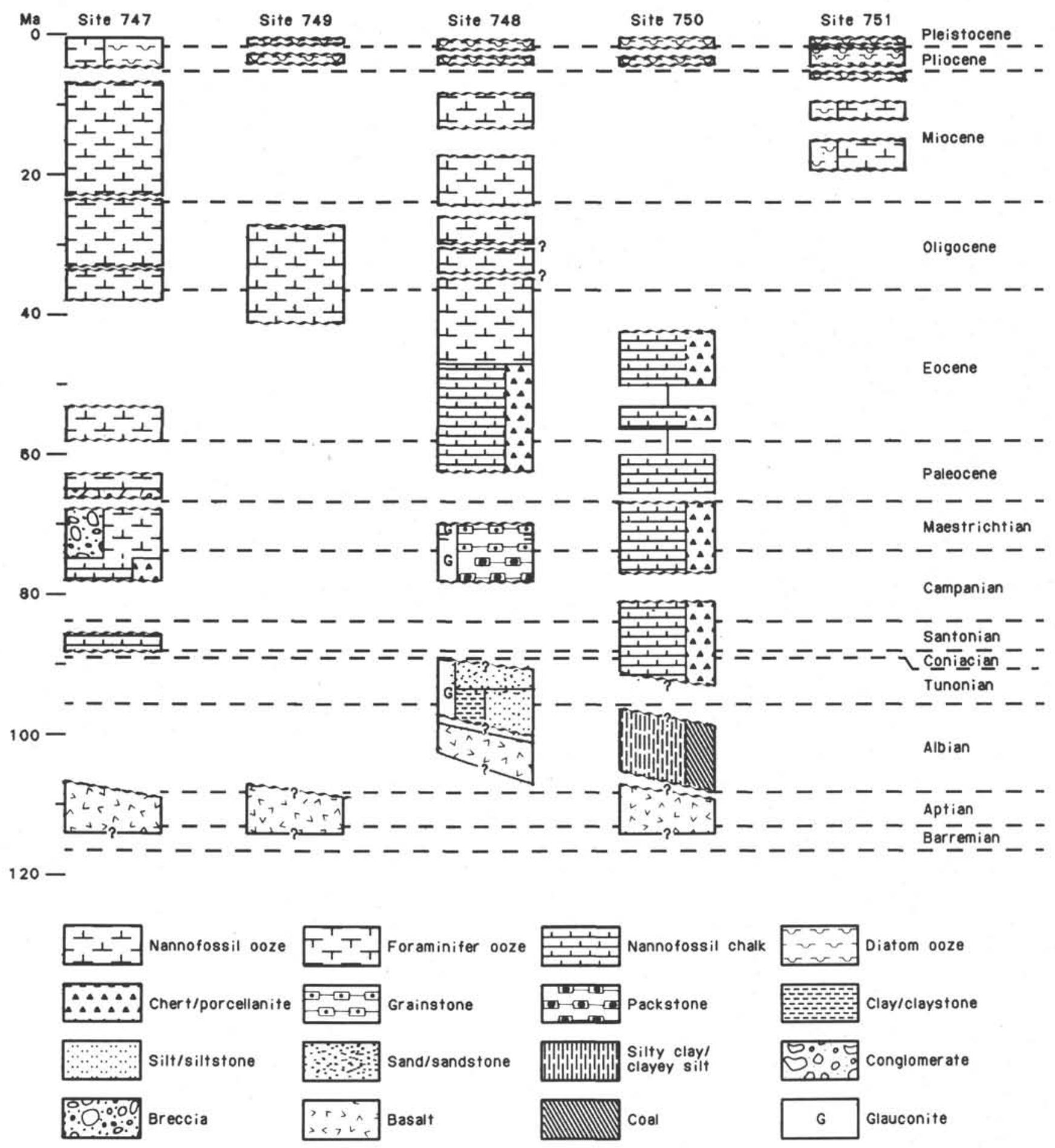

Figure 2. Simplified stratigraphy for Leg 120 sites (from Schlich, Wise, et al., 1989, p. 77, fig. 4).

\section{BIOSTRATIGRAPHY}

\section{Biostratigraphic Scheme}

The difficulties linked to correlating between high- and lowlatitude sedimentary sections through biostratigraphy are now well recognized. Different authors attempted to remedy to them using different methods. One approach is to modify an existing zonal scheme by substituting new boundary markers; another approach is to define new zonal intervals. For calcareous nannofossil stratigraphy, Perch-Nielsen (1977) criticized such practices, and it seems useful to reiterate her words of caution. Modifying zonal schemes often contributes to increased stratigraphic confusion unless the range of the substitute marker is well established with respect to that of the original marker, which is usually not the case. Creating new zonal intervals adds to the complexity of biostratigraphic correlation, because the newly defined zones are not useful unless correlatable to existing 
Table 1. Paleogene calcareous nannofossil stratigraphy, Hole 747A.




Table 1 (continued).
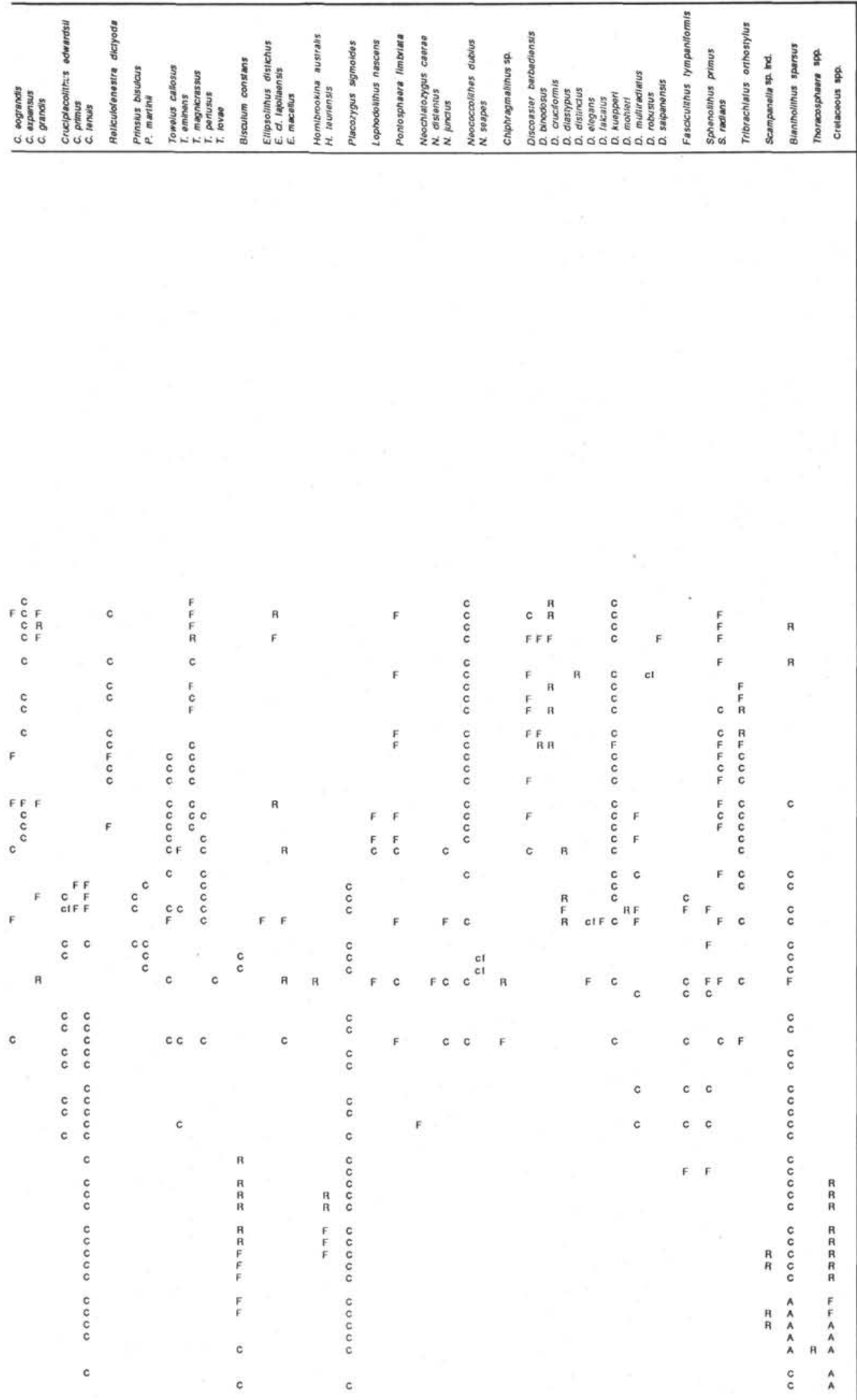
Table 2. Paleogene calcareous nannofossil stratigraphy, Hole 747C.

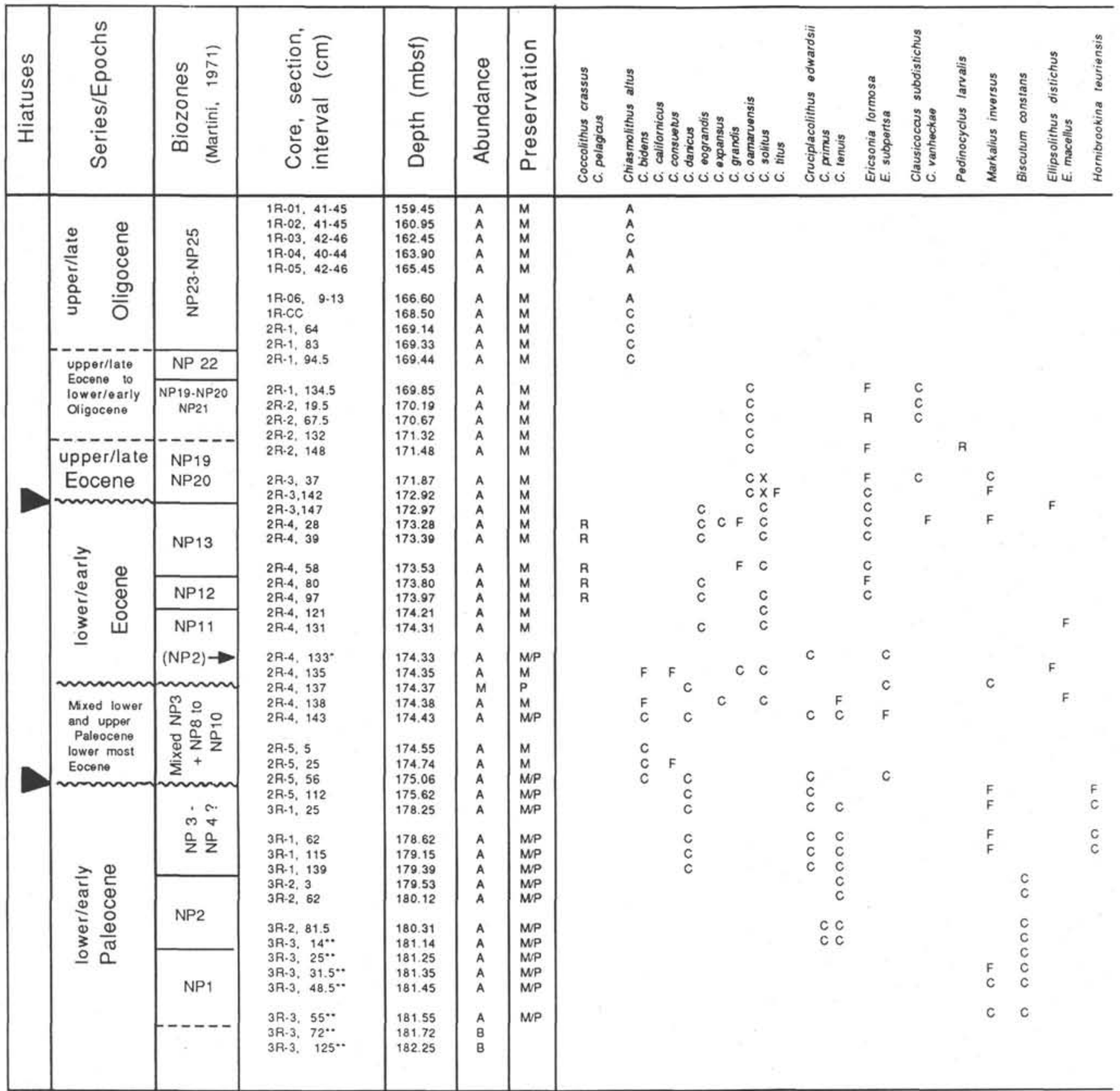

Notes: (") intradast in nannofossil oozes and $\left({ }^{*}\right)$ intraclast in volcanic deposit

schemes (which is not immediately possible). In addition, new zonal intervals have too often been proposed for local rather than regional use.

A zonal scheme was proposed by Wise (1983) to subdivide the Oligocene sediments from the Falkland Plateau region (Table 6). Although appropriate for the stratigraphy of the Weddell Sea and Georgia Oligocene sediments (Shipboard Scientific Party, 1988a, 1988b), the scheme was not applicable to the Oligocene sections recovered from the Kerguelen Plateau. At Sites 747, 748, and 749, the highest occurrence of Reticulofenestra bisecta precedes that of Chiasmolithus altus, and Clausicoccus subdistichus is very rare.

Wise and Wind (1976) defined the Heliolithus universus Zone in the Paleocene of the Falkland Plateau and, accord- ingly, modified the definition of Martini's Zone NP5 (= Fasciculithus tympaniformis Zone) (Table 7). This alteration to Martini's zonal scheme was not applicable to the Paleogene sediments from the Kerguelen Plateau because of the extremely rare occurrence of Heliolithus universus, which is restricted to the base of Zone NP9 (in Hole 748C).

Two main zonal schemes based on the ranges of calcareous nannofossils are dependable for Cenozoic stratigraphy. Both have been correlated to the main planktonic foraminifer schemes and to the magnetostratigraphic record (e.g., Berggren et al., 1985). Bukry's biozonation (1973, 1975) was developed for equatorial Pacific sediments, whereas Martini's scheme (1971) was based on sections from broad latitudinal and sedimentologic settings. Because of its broader geo- 
Table 2 (continued).

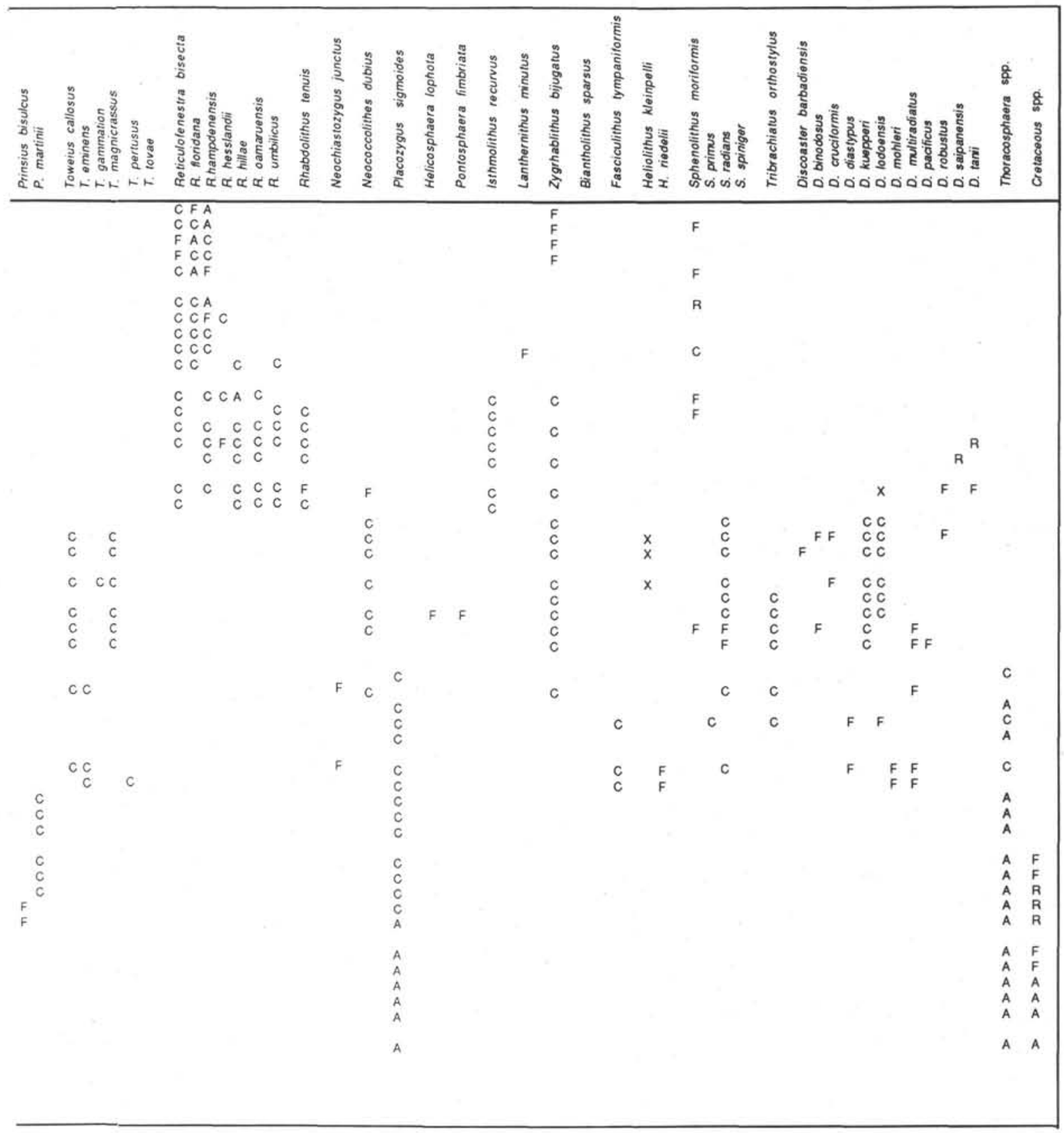

graphic applicability, Martini's standard zonation is followed here. The upper Oligocene sections recovered from the Kerguelen Plateau, however, cannot be subdivided, because the primary and secondary markers (species of the genera Sphenolithus and Helicosphaera, and of Pontosphaera, respectively) are absent. In addition, a number of zonal boundaries cannot be delineated precisely, either because some markers are absent (such as Tribrachiatus bramlettei and $T$. contortus for the NP9/NP10 and NP10/NP11 boundaries), and others are extremely rare (such as Discoaster saipanensis), or because of the scattered occurrences of index species (such as Nannotetrina fulgens). The difficulties encountered in subdividing the Paleogene sediments recovered during Leg 120 are similar to those discussed by Perch-Nielsen (1977) with regard to the biostratigraphy of the Paleogene sediments from the southwest Atlantic Ocean.

Zone NP1 was easily characterized by the high frequency of Thoracosphaera spp. (which does not occur in high-latitude late Maestrichtian assemblages; see Ehrendorfer and Aubry, this volume) and the fairly common occurrence of Biantholithus sparsus.

Cruciplacolithus primus, C. tenuis, and Chiasmolithus danicus were abundant and allowed a clear delineation of the bases of Zones NP2 and NP3, respectively. The NP3/NP4 zonal boundary, however, could not be precisely drawn because of the absence of Ellipsolithus macellus in lower Paleocene sediments. It is not clear whether this absence results from poor preservation or reflects unfavorable ecologic 
Table 3. Paleogene calcareous nannofossil stratigraphy, Hole 748B.

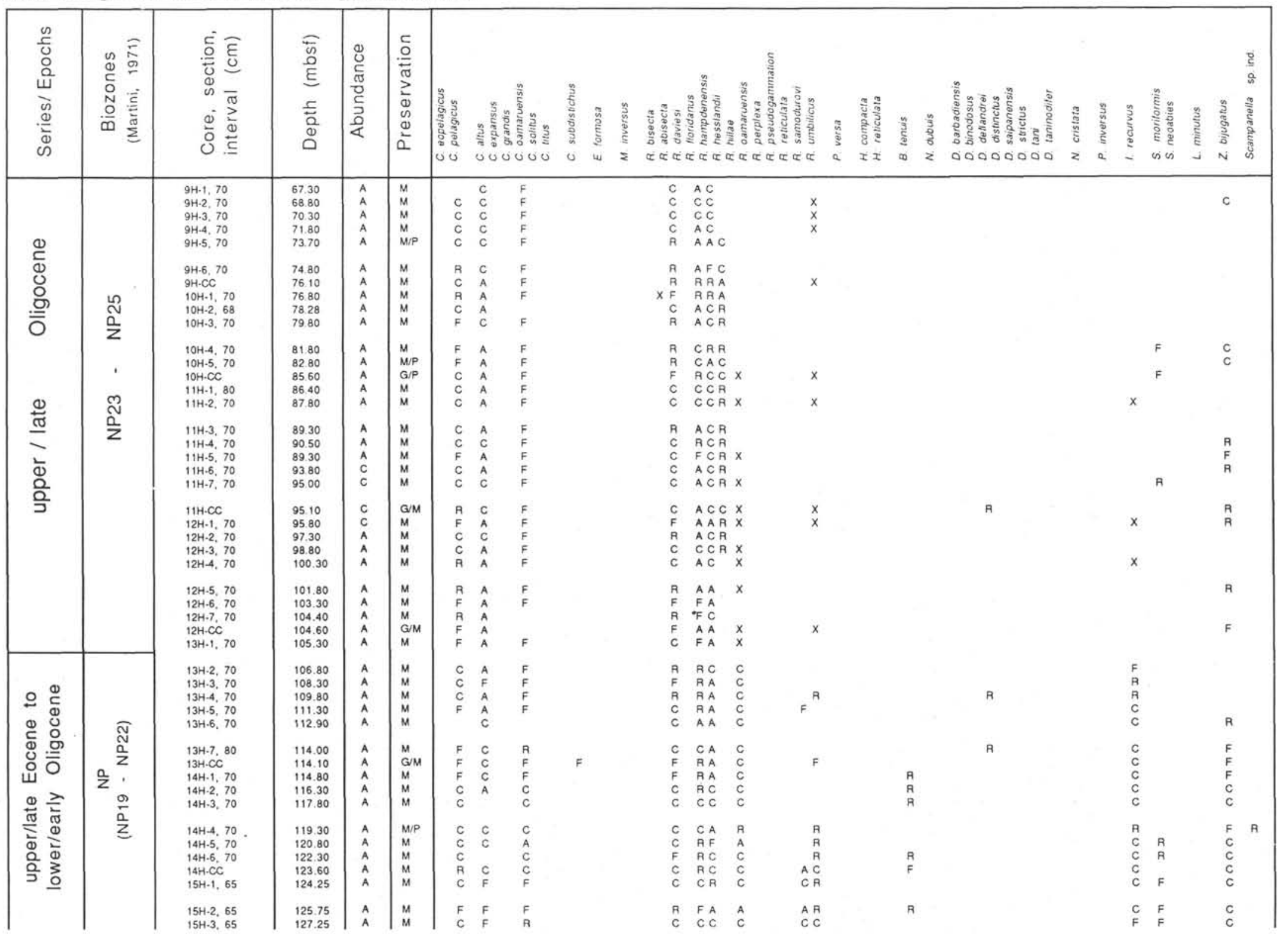


Table 3 (continued).

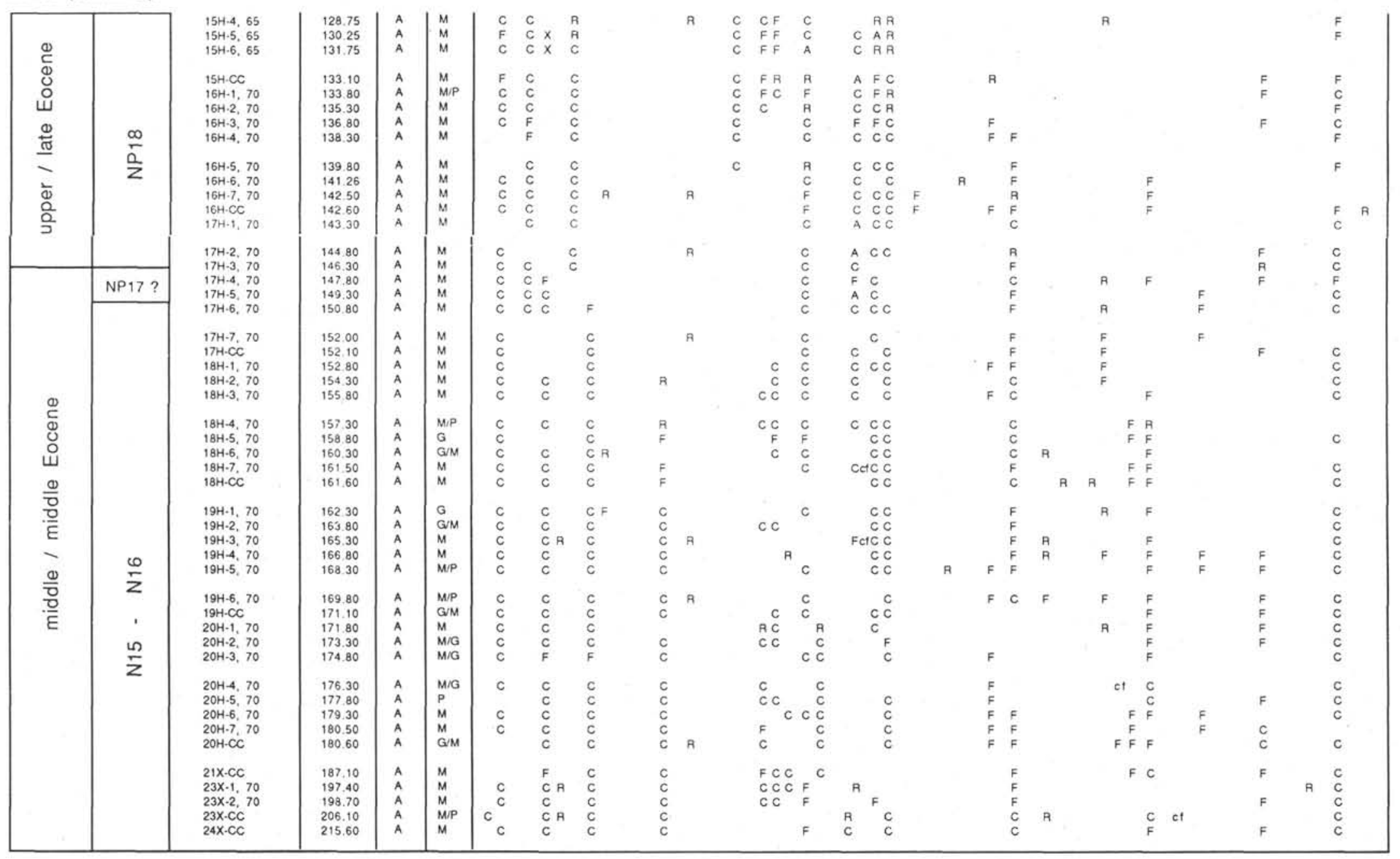


Table 4. Paleogene calcareous nannofossil stratigraphy, Hole 748C.

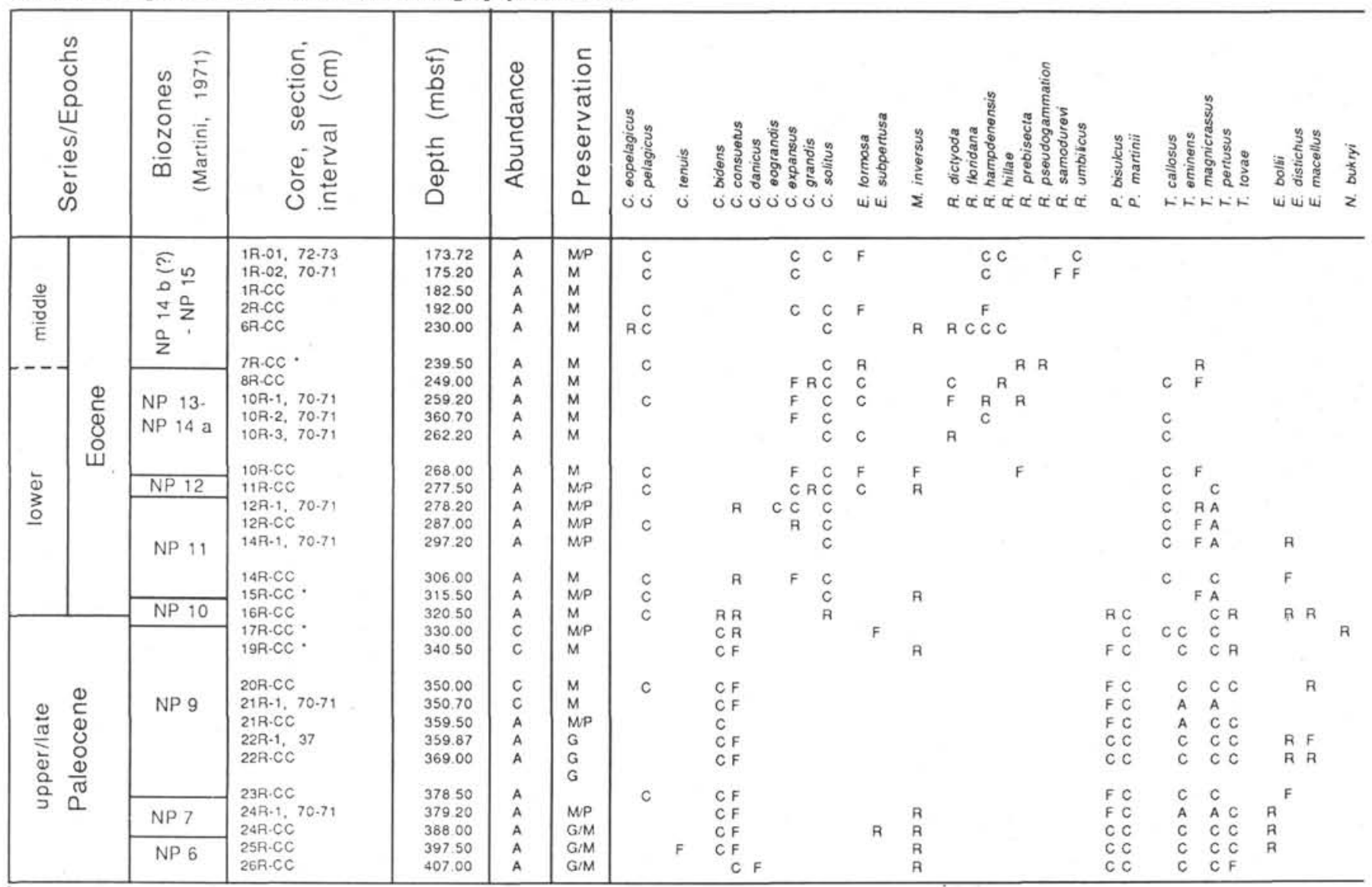

Note (") scraping from chert tragments

conditions. Ellipsolithus macellus is fairly common in the upper Paleocene and lower Eocene assemblages from the Kerguelen Plateau. Following Perch-Nielsen (1985), assemblages that yield Chiasmolithus danicus and Sphenolithus primus but lack representatives of the genus Fasciculithus were assigned to Zone NP4.

The recognition of Zone NP10 was based on the co-occurrence of Chiasmolithus bidens and $C$. solitus and the absence of Fasciculithus tympaniformis. Delineation of the NP9/NP10 and NP10/NP11 zonal boundaries based on these criteria is approximate, and the relation between the stratigraphic range of species in Zone NP10 and the Paleocene/Eocene boundary requires revision (see discussion in Aubry et al., 1988).

Discoaster sublodoensis is restricted to a thin stratigraphic interval where it occurs with Discoaster kuepperi and D. lodoensis. The occurrence of these three species suggests a zonal assignment to Subzone NP14a (= CP12a of Okada and Bukry, 1980; Aubry, 1991). The absence of D. sublodoensis above this interval may indicate an unconformity, Zone NP14b and part of Zone NP15 being missing. Alternatively, it indicates that the $\mathrm{HO}$ of this taxon is diachronous. The sharp decrease in diversity that calcareous nannofossil assemblages exhibit in the lowest middle Eocene may support this latter interpretation. Rhabdosphaera inflata was not found, and only scarce, poorly preserved representatives of the genus Nannotetrina were observed. A review of the literature dealing with southern latitude middle Eocene assemblages (e. g., Edwards and Perch-Nielsen, 1975; PerchNielsen, 1977) suggests that the geographic distribution of $D$. sublodoensis is latitudinally controlled.
The NP15-NP16 zonal interval could not be subdivided satisfactorily. The rather homogeneous calcareous nannofossil assemblages in this interval on the Kerguelen Plateau yield no biozonal markers, except for sporadic specimens tentatively assigned to Nannotetrina fulgens. The LO of Chiasmolithus oamaruensis was somewhat difficult to locate because of the occurrence of a few specimens reminiscent of this species in the uppermost range of Chiasmolithus solitus (which HO was clearly delineated). Chiasmolithus grandis does not occur (or is extremely rare) in the middle Eocene sections recovered during Leg 120. The $\mathrm{HO}$ of Pseudotriquetrorhabdulus inversus between the LO of typical $C$. oamaruensis and the $\mathrm{HO}$ of $C$. solitus at Site 748 may be used to confirm assignment to Zone NP17.

Although the NP19-NP20 (Aubry, 1983) to NP22 zonal interval could not be subdivided at Site 748 , the sequential FO and LO of Isthmolithus recurvus, Discoaster saipanensis, Ericsonia formosa and Reticulofenestra umbilica (and $R$. hillae) were observed at Hole $747 \mathrm{C}$. Comparison of the stratigraphic ranges of calcareous nannofossil species in the upper Eocene and lower Oligocene sediments from Sites 747 and 748 reveals strong diachrony of the highest and lowest occurrences between the two sites (see discussion below).

\section{Paleogene Sediments Recovered during Leg 120: Calcareous Nannofossil Stratigraphy}

Because of the major unconformities, no continuous $\mathrm{Pa}$ leogene section was recovered during Leg 120 . However, sites complemented each other in providing different parts of the 
Table 4 (continued).

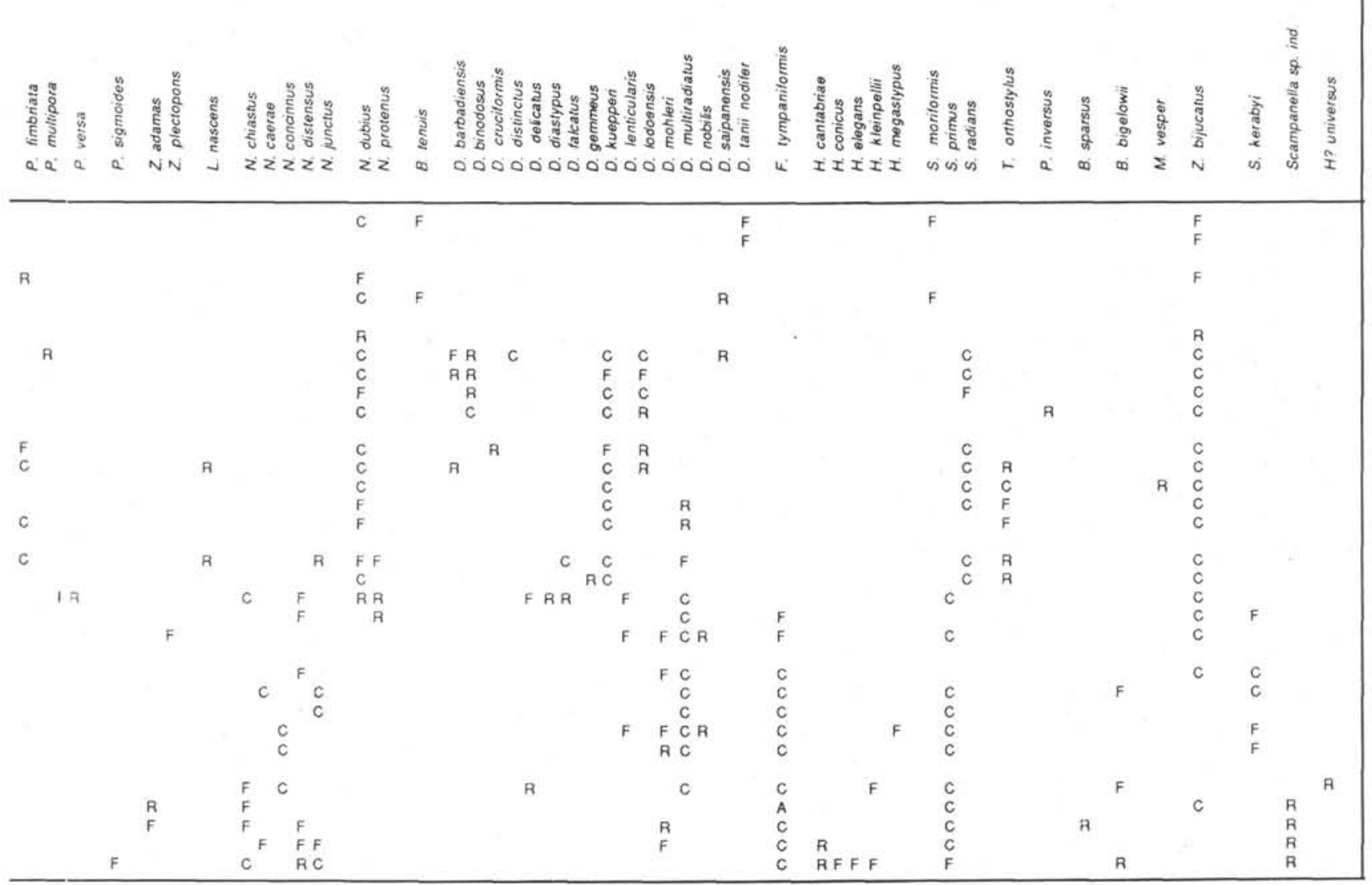

record, so that a virtually complete composite Paleogene section was recovered from the Kerguelen Plateau. Only the lowermost upper Paleocene was not recovered.

Paleocene sediments were essentially nannofossil chalks with micrite and chert, and recovery was moderate. Recovery was excellent through the upper Eocene and Oligocene sediments, primarily consisting of nannofossil oozes and chalks. It was extremely poor throughout the middle and lower Eocene because of the thick chert formations. When only chert fragments were recovered, stratigraphic continuity was verified by examining slides prepared from the partly silicified nannofossil oozes that encrusted the chert.

As explained above, calcareous nannofossil stratigraphy alone was insufficient to evaluate the continuity of sections. Magnetostratigraphy was essential for delineating the Oligocene/Miocene boundary and for estimating the continuity of the Oligocene sections (see Heider et al., this volume, Chapter 15 ; Inokuchi, this volume). Calcareous nannofossil and planktonic foraminifer stratigraphies complemented each other for interpreting Eocene and Paleocene sections.

\section{Site 747}

Three holes were drilled at Site 747, which is located in the transition zone between the northern and southern parts of the Kerguelen Plateau $\left(54^{\circ} 48.68^{\prime} \mathrm{S}, 76^{\circ} 47.64^{\prime} \mathrm{E}\right)$, approximately $500 \mathrm{~km}$ South of the Polar Front. Hole 747B ended in upper Miocene oozes, and Holes $747 \mathrm{~A}$ and $747 \mathrm{C}$ penetrated stratigraphically complex Paleogene sections revealing the intricate tectonic/paleoceanographic history of the region.
The stratigraphy of the Paleogene sections recovered from these latter holes is described in Aubry and Berggren (1989), and the calcareous nannofossil ranges that support the authors' interpretation of the sections are given in Tables 1 and 2. Upper Oligocene oozes (equivalent to Zones NP23 to NP25 as inferred from magnetobiostratigraphic correlations, see Berggren et al., 1985) apparently rest unconformably over an extremely condensed, but virtually continuous, uppermost Paleocene to lower Eocene section in Hole 747A. In addition, a condensed, apparently continuous upper Eocene-lower Oligocene sequence is unconformably sandwiched in Hole $747 \mathrm{C}$ between upper Oligocene and upper Paleocene-lower Eocene sections equivalent to those encountered in Hole 747A (Fig. 3; poor recovery prevented recovery of this sequence from Hole $747 \mathrm{~A}$ ). The 5 -cm-thick phosphatic layer in Section 120-747C-2R-1 expresses the unconformity between the lower and upper Oligocene oozes, as indicated by planktonic foraminifer stratigraphy (Berggren, this volume).

In both holes, the upper Paleocene-lower Eocene sequence lies unconformably over lower Paleocene chalks (Zone NP2 to Zone NP3, and perhaps Zone NP4). They, in turn, are unconformable with Upper Cretaceous nannofossil chalks (see Quilty, this volume; Watkins, this volume) from which they are separated by a polygenic breccia. Recovery was very poor in the breccia and its contact with the Cretaceous chalks is unknown. However, intraclasts of calcareous nannofossil oozes occur in the upper part of the breccia, which indicates that at least part of it was deposited during the early Paleocene (Biochron NP2). Some of the intraclasts 
Table 5. Paleogene calcareous nannofossil stratigraphy, Hole 749.

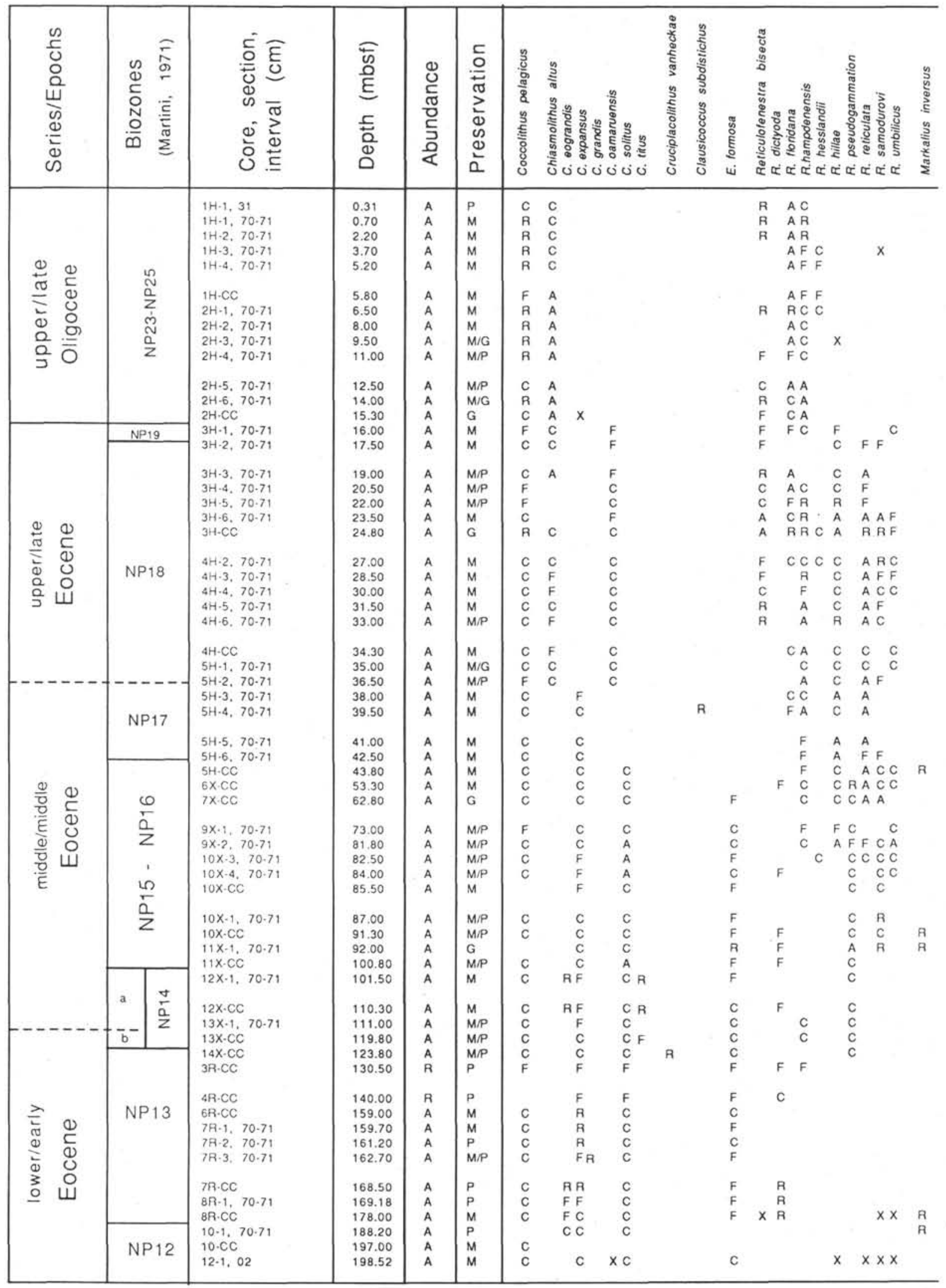


Table 5 (continued).
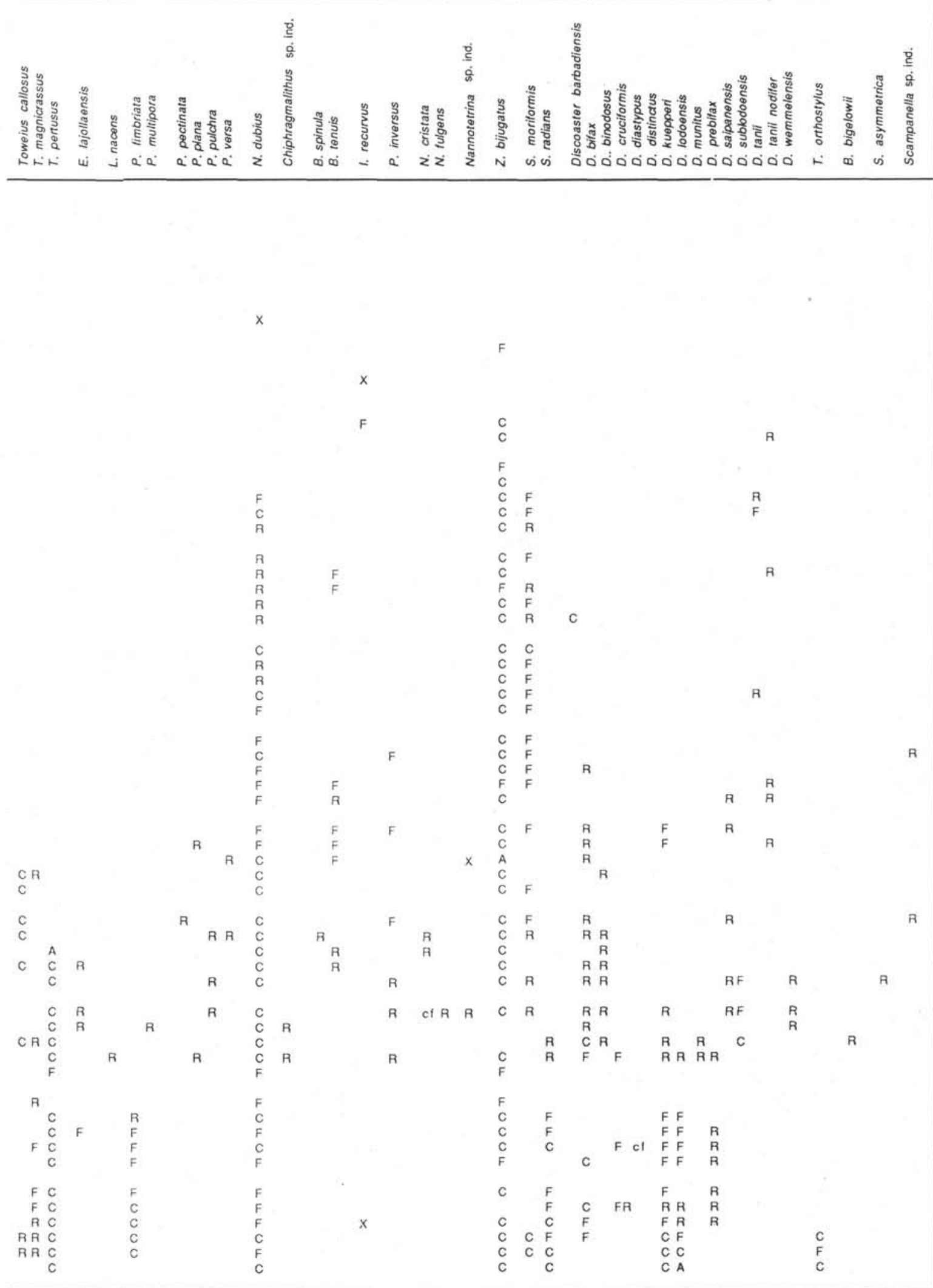
Table 6. Biozonal scheme proposed by Wise (1983) for Oligocene sediments from the Falkland Plateau.

\begin{tabular}{|c|c|c|c|c|}
\hline Zones & & \multicolumn{3}{|l|}{ Index species } \\
\hline $\begin{array}{l}\text { Reticulofenestra } \\
\text { bisecta }\end{array}$ & & & & క్ \\
\hline $\begin{array}{l}\text { Chiasmolithus } \\
\text { altus }\end{array}$ & & के & ปี & 2 \\
\hline $\begin{array}{l}\text { Reticulofenestra } \\
\text { daviesi }\end{array}$ & 胥 & ডั & & \\
\hline $\begin{array}{l}\text { Clausicoccus } \\
\text { fenestratus }\end{array}$ & ฐู & I & & \\
\hline & & & & \\
\hline
\end{tabular}

T LAD

Last common occurrence

embedded in the breccia yield assemblages indicative of Zone NP1 with abundant Thoracosphaera spp. (which do not occur at high latitude in the Maestrichtian) and Biantholithus sparsus, a species often regarded as the first typical Cenozoic calcareous nannofossil taxon to have evolved above the Cretaceous/Paleogene boundary. Other intraclasts yield $\mathrm{Cru}$ ciplacolithus tenuis and $C$. primus, indicative of Zone NP2. The calcareous oozes immediately overlying the breccia in which thin particles of the latter are interspersed belong to Zone NP2.

\section{Site 748}

A virtually complete Oligocene through upper Paleocene section was penetrated at Site $748\left(58^{\circ} 26.45^{\prime} \mathrm{S}, 78^{\circ} 58.89^{\prime} \mathrm{E}\right)$, on the Southern Kerguelen Plateau in the western part of the Raggatt Basin, east of the Banzare Bank. Recovery was poor in the lower and middle Eocene and in the Paleocene because of the presence of chert; therefore, the stratigraphic resolution for this interval is very limited. Scraping nannofossil oozes encrusted on the chert provided enough material to insure biostratigraphic control and allowed us to record the distribution of calcareous nannofossils throughout the Paleogene at Site 748 (Tables 3 and 4).

Although the Paleogene section at Site 748 is regarded as virtually complete, there may be at least two unconformities reflecting short hiatuses or two condensed intervals (Fig. 4). Zone NP17 is difficult to characterize at Site 748 and, if present, it is only a few meters thick $(4-5 \mathrm{~m})$ in contrast to the thick interval assigned to Zone NP18 above and Zones NP16 to NP15 below. Zone NP17 at Site 748 may represent a condensed section or may correspond to a hiatus of 1 or $2 \mathrm{~m} . \mathrm{y}$. An unconformity may also occur near the Paleocene/Eocene boundary, as indicated by the truncation of Zone NP10. Poor recovery in this interval precludes a reliable stratigraphic interpretation of this level. In addition, it is unclear whether Zone NP14 is present. Discoaster sublodoensis, which occurs at Site 749, was not found at Site 748 .

The oldest Paleogene sediments recovered from Site 748 are of early late Paleocene age. They rest unconformably on Maestrichtian chalks, and the hiatus between theses deposits is estimated to be at least 6 m.y. (Schlich, Wise, et al., 1989, pp. 157-235).
Table 7. Modifications to Martini's zonal scheme (1971) for Paleocene sediments from the Falkland Plateau as suggested by Wise and Wind (1976).

\begin{tabular}{|c|c|c|c|}
\hline Zones & \multicolumn{3}{|c|}{ Index species } \\
\hline $\begin{array}{l}\text { Discoaster } \\
\text { multiradiatus }\end{array}$ & & & 1 \\
\hline $\begin{array}{l}\text { Heliolithus } \\
\text { universus }\end{array}$ & & 7 & 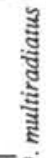 \\
\hline $\begin{array}{l}\text { Fasciculithus } \\
\text { involutus } \\
\text { (NPS) }\end{array}$ & 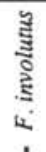 & 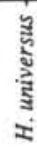 & $\theta$ \\
\hline
\end{tabular}

\section{Site 749}

A thick section of Oligocene to lower Eocene nannofossil oozes was penetrated at Site 749 , on the western flank of the Banzare Bank $\left(58^{\circ} 43.03^{\prime} \mathrm{S}, 7^{\circ} 24.45^{\prime} \mathrm{E}\right)$, on the Southern Kerguelen Plateau. Approximately $30 \mathrm{~cm}$ of Pleistocene diatom oozes overlie $198 \mathrm{~m}$ of Paleogene oozes. Recovery was excellent in the Oligocene and upper Eocene but poor in the middle and lower Eocene section as a result of chert intercalations. Stratigraphic subdivisions at this site are fairly straightforward (Table 5 and Fig. 5), except for the Oligocene oozes (equivalent to Zones NP23-NP25, as indicated by the magnetostratigraphy [Heider et al., this volume, Chapter 15] and the planktonic foraminifer stratigraphy [Berggren, this volume]) and the NP15NP16 zonal interval (which lacks index species).

The range of Isthmolithus recurvus is truncated; thus, it is clear that there is an unconformity between the Oligocene and upper Eocene. However, in the absence of rosette-shaped discoasters and Ericsonia formosa, it was not possible to determine whether the range of $I$. recurvus indicates Zone NP22 (lower Oligocene) or Zones NP19-NP20 (upper Eocene). Planktonic foraminifer stratigraphy (Berggren, this volume) indicates that the upper Oligocene sediments are unconformable with the upper Eocene oozes and that no lower Oligocene occurs at this site. By correlation, Section 120-749A-3H-1 was assigned to Zone NP19.

As at Site 748 , Zone NP17 is difficult to characterize. If present, as suggested by the occurrence of Pseudotriquetrorhabdulus inversus, it is rather thin.

The thickness of Zone NP14 is uncertain, and it is unsure whether only the lower part (Subzone NP14a) or the whole zone is present. This uncertainty results from the poor recovery in this interval as well as from the fact that poorly preserved discoasters, which may correspond to $D$. lodoensis, occur in an interval that corresponds to the total range of $D$. sublodoensis at Site 749.

The interval assigned to Zones NP13 and NP12 is uncommonly thick and is interpreted as resulting from the redeposition of sediments (Schlich, Wise, et al., 1989, pp. 237-274). The oldest sediments above the basalt at Site 749 belong to Zone NP12, but the basalt is middle Cretaceous (Schlich, Wise, et al., 1989, pp. 237-274).

\section{Site 750}

This site is located on the Southern Kerguelen Plateau $\left(57^{\circ} 35.54^{\prime} \mathrm{S}, 81^{\circ} 14.42^{\prime} \mathrm{E}\right)$ in the eastern part of the Raggatt 


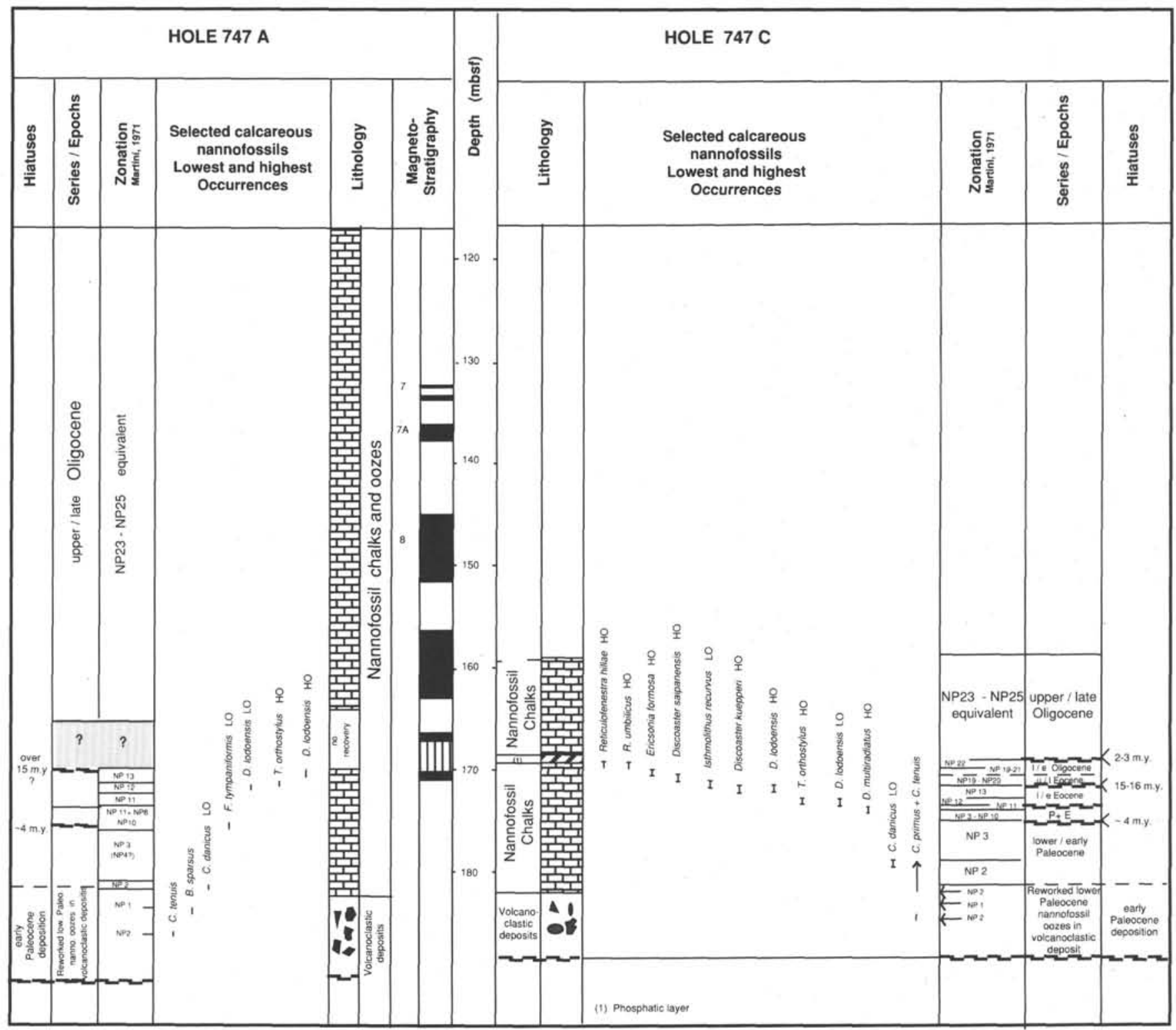

Figure 3. Depositional history, Site 747.

Basin, west of the deep Labuan Basin, approximately $900 \mathrm{~km}$ south of the present-day Polar Front. It was washed and cored interval by interval through middle and lower Eocene oozes, and continuously cored through a Paleocene-Maestrichtian sequence that yielded a nearly complete, but drilling-disturbed, Cretaceous/Paleocene boundary.

Because of the discontinuous record from Site 750 , no further data than those given in the preliminary reports (Schlich, Wise, et al., 1989, pp. 277-337) are provided. The changes in the calcareous nannoplankton at the Cretaceous/ Paleogene boundary are described in Ehrendorfer and Aubry (this volume).

\section{Global and Local Diachrony}

Previous biostratigraphic studies of Paleogene southern high-latitude sediments have revealed strong diachrony in the LOs and HOs of many taxa that serve as index species at low latitudes, particularly in the upper Eocene (see, for instance, Perch-Nielsen, 1977; Wise and Wind, 1976; Edwards and
Perch-Nielsen 1975; Wise, 1983). Sites drilled on the Kerguelen Plateau provide an opportunity to illustrate some aspects of this twofold diachrony.

\section{Global Diachrony}

First, there is diachrony between these high-latitude sites and low-latitude regions. Figure 6 gives the correlations that are currently drawn between magnetostratigraphy and Martini's biozonal scheme for the upper middle Eocene to lower upper Oligocene (from Berggren et al., 1985). Thick bars to the right of this scheme indicate the levels where the FAD (first appearance datum) and LAD (last occurrence datum) of a number of stratigraphically important taxa occur with respect to this scheme. Next to the thick bars, thin lines show where the LO (lowest occurrence) and HO (highest occurrence) of the same taxa are located at Hole $747 \mathrm{C}$ and Sites 748 and 749 , as deduced, in most instances, from magnetostratigraphy (Heider et al., this volume, Chapter 15; Inokuchi, this volume) and from planktonic foraminifer stratigraphy (Berg- 


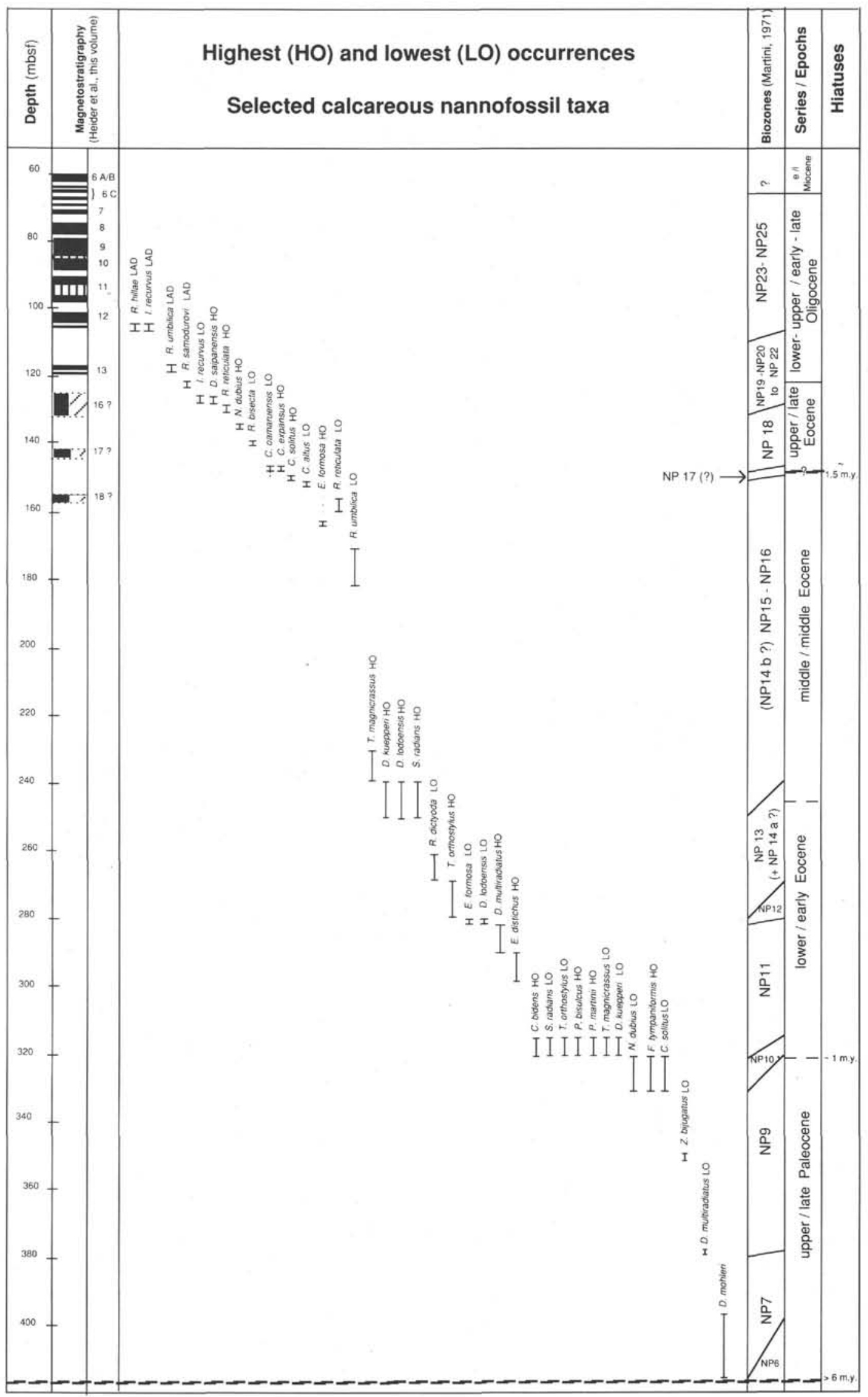

Figure 4. Depositional history, Site 748. 


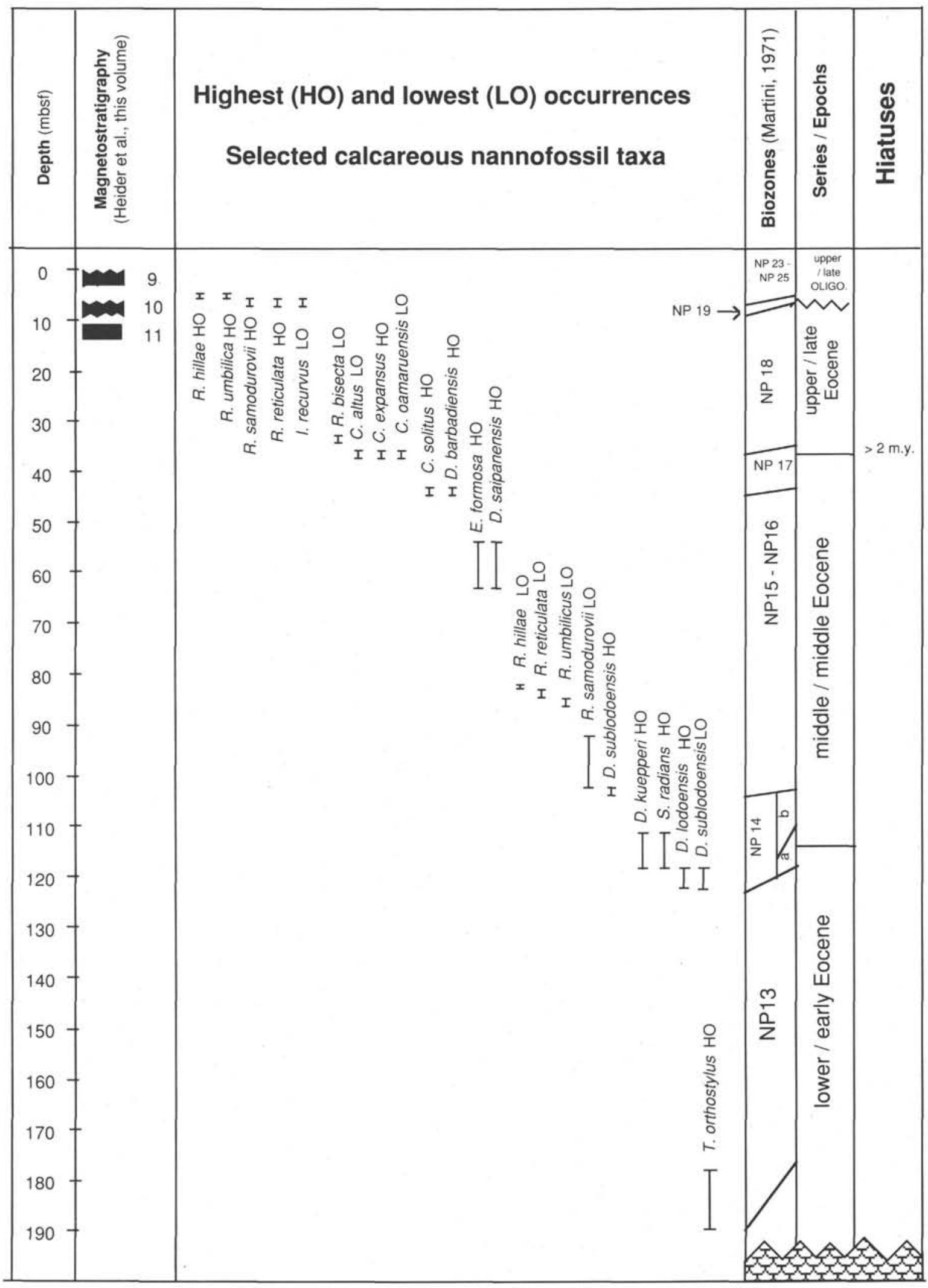

Figure 5. Depositional history, Site 749. 
gren, this volume). Because the magnetostratigraphic record of the Paleogene of the Kerguelen Plateau is incomplete (most chrons in the middle to upper Oligocene interval comprise two or three normal events, but chrons identified in the Paleogene of the Kerguelen Plateau correspond to a single normal event), there is a large uncertainty (dashed line) as to the precise position of most of the LOs and HOs considered. Despite this uncertainty, diachrony is obvious if we accept that the magnetozones recorded at Sites 747,748 , and 749 were correctly identified.

Diachrony does not seem to be restricted to the truncation of the ranges of such taxa as Ericsonia formosa, Discoaster saipanensis, and Reticulofenestra reticulata. The HOs of Reticulofenestra hillae and Isthmolithus recurvus seem to be correlated with Chron C12N at Site 748, and the LOs of the latter taxon as well as that of Chiasmolithus oamaruensis may occur earlier than previously thought. This apparent "global" diachrony requires further studies before its full stratigraphic/chronologic and evolutionary significance can be determined.

\section{Local Diachrony}

Second, there is a biogeographically/paleoceanographically significant local diachrony between sites drilled on the Kerguelen Plateau. Site $747\left(54^{\circ} 48.68^{\prime} \mathrm{S}\right)$ is located about $4^{\circ} \mathrm{N}$ of Sites $748\left(58^{\circ} 26.45^{\prime} \mathrm{S}\right)$ and $749\left(58^{\circ} 43.03^{\prime} \mathrm{S}\right)$.

As discussed above (Table 2 and Fig. 3), Martini's biozonal scheme was applicable to the stratigraphic subdivision of the thin upper Eocene-lower Oligocene sequence recovered from Site 747. Sequential occurrences of Isthmolithus recurvus, Discoaster saipanensis, Ericsonia formosa, and Reticulofenestra umbilica were observed at Site 747 but not at Site 748 , from which a virtually complete section across the Eocene/Oligocene boundary was retrieved (see above). At Site 748 , the HO of Discoaster saipanensis is located within lower upper Eocene Zone NP18, whereas the HO of Ericsonia formosa at Sites 748 and 749 is within middle Eocene Zone NP16.

Comparison between sites is limited because of the incompleteness of the upper Eocene-lower Oligocene section recovered from Site 749. However, the available data show undoubtedly diachronous events among Leg 120 sites, related either to the latitudinal difference of $4^{\circ}$ or to the proximity of Site 747 to a coast (see discussion on the evolution of the Kerguelen-Heard Plateau in Schlich, Wise, et al., 1989, pp. $7-23)$. The significance of this diachrony is briefly discussed below.

Aside from these diachronous late Paleogene events deduced from magnetobiostratigraphic correlations, there seem to be a number of other diachronous occurrences in the Paleocene and early Eocene. They are difficult to document because of poor recovery, but the lower Eocene occurrence of Prinsius bisulcus, a species restricted to the Paleocene NP4NP9 zonal interval according to Perch-Nielsen (1985), is noteworthy.

\section{PALEOGENE CALCAREOUS NANNOFOSSIL ASSEMBLAGES FROM THE KERGUELEN PLATEAU: PALEOBIOGEOGRAPHIC/ PALEOCEANOGRAPHIC IMPLICATIONS}

Quantitative analysis of the Cenozoic calcareous nannofossil assemblages recovered from the Kerguelen Plateau is in progress and will be published separately. Semiquantitative data regarding the range and abundance of the calcareous nannofossil species in the Paleogene sediments recovered from the Kerguelen Plateau allow, however, preliminary remarks that are significant for understanding the paleocean- ographic evolution of the Southern Indian Ocean during the Cenozoic.

The Paleogene calcareous nannofossil assemblages from the Kerguelen Plateau show striking features concerning their diversity, composition and latitudinal differentiation.

\section{Diversity of the Assemblages}

Changes in diversity can be summarized as follows: calcareous nannofossil diversity increased throughout the Paleocene and culminated in the late early Eocene. Subsequently, it decreased rapidly in a stepwise manner from the middle Eocene to the Oligocene.

Because of the strong dominance of few taxa (particularly at times of low diversity) and also because of unsettled taxonomic concepts in some genera (e.g., Reticulofenestra) there are difficulties in quantifying the variations in number of calcareous nannofossil taxa throughout the Paleogene. Estimates from the data presented here (Tables 1 to 5) indicate that the number of species increased from $<10$ in the early Paleocene to $>25$ in the early Eocene, and then decreased in a stepwise fashion to 6 taxa in the late Oligocene. This number further decreased to 2 basic taxa (Coccolithus pelagicus and Reticulofenestra pseudoumbilica s.1. in the Miocene.

Two major reductions in diversity occurred: near the early/middle Eocene boundary and near the early/late Oligocene boundary. There is no important change in diversity associated with the Eocene/Oligocene boundary. In lowlatitude regions, speciation (or migration of taxa from shallow water areas to the open ocean) occurred above the early/late Oligocene boundary, suggesting some recovery following the events that led to a reduction in diversity near the Eocene/ Oligocene boundary. In contrast, no late Oligocene rebound is shown by the calcareous nannoflora from the Kerguelen Plateau following the extinction of Reticulofenestra umbil$i c a / R$. hillae. In other words, there was no recovery in the calcareous nannoflora in this high-latitude region following the early Oligocene glaciation, which suggests that severe conditions persisted throughout the Oligocene. This is in agreement with the isotopic results obtained from Site 748 (Zachos et al., this volume). The timing of increased reduction in diversity in the Miocene is difficult to assess from the material recovered from Leg 120 because of intensive reworking close to the Oligocene/Miocene boundary.

\section{Composition of Assemblages}

Strong contrasts in the composition of assemblages of different ages occur. Species of the genera Cruciplacolithus and Chiasmolithus were overwhelmingly dominant in early Paleocene assemblages. The most diversified early Eocene assemblages were strongly dominated by species of the genus Toweius. Late middle Eocene assemblages were dominated by representatives of the genera Chiasmolithus $(C$. solitus and $C$. expansus) and Reticulofenestra ( $R$. pseudogammation, $R$. umbilica, and $R$. samodurovii), whereas the major components of the early late Eocene assemblages were Reticulofenestra reticulata and Chiasmolithus oamaruensis. The early Oligocene assemblages were dominated by Reticulofenestra hillae, $R$. umbilica, and $R$. samodurovii. Strong fluctuations in abundance among four species (Reticulofenestra bisecta, $R$. floridana, Coccolithus pelagicus, and Chiasmolithus altus) occurred in the upper Oligocene assemblages, which may reflect short-term climatic variations (Aubry, unpubl. data).

The frequency changes of discoasters in the Paleogene assemblages of the Kerguelen Plateau parallel the changes in the overall diversity of these assemblages. Discoasters were common in the late Paleocene assemblages and even more 
Figure 6. Diachronous middle Eocene through lower upper Oligocene calcareous nannofossil occurrences. Comparison between $\mathrm{HO}$ and FO of selected taxa in the Paleogene from the Kerguelen Plateau and their FAD and LAD as established from low-latitude regions (from Berggren et al., 1985).

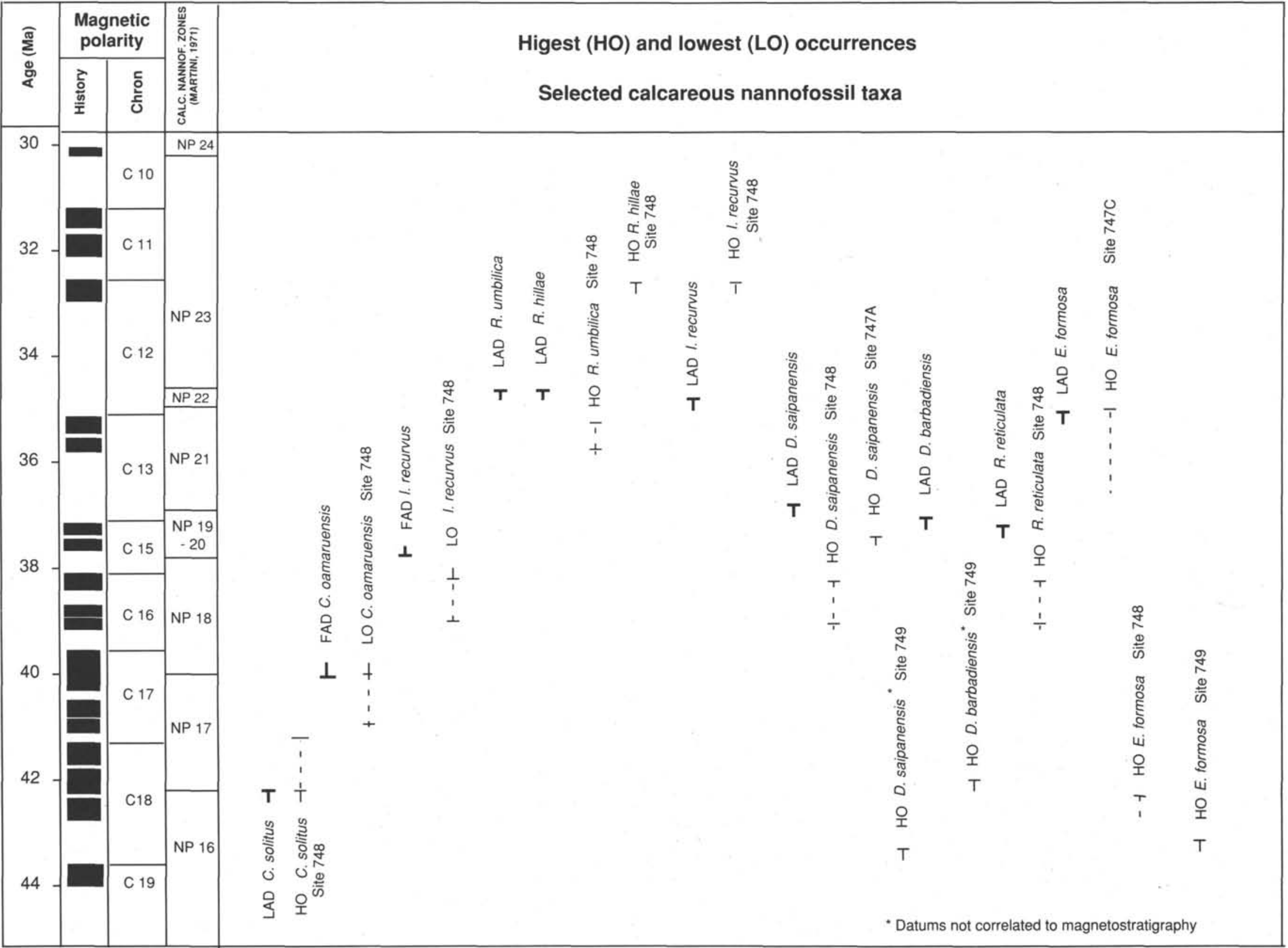


common in early Eocene assemblages; however, their frequency decreased dramatically close to the early/middle Eocene boundary (close to the NP14a/NP14b zonal boundary), after which they occurred only rarely. Changes in the abundance and diversity of the discoasters and concomitant changes in diversity of the Paleogene assemblages best reflect climatic deterioration, and suggest that the most pronounced Paleogene cooling event in the southern Indian Ocean occurred near the early/middle Eocene boundary. This may also be true for northern high latitudes, as suggested by the study of Bukry and Snavely (1988), who remarked that the Oregon Coast Range was differentiated from southern California as early as the late early Eocene.

\section{Latitudinal Differentiation of Assemblages}

A comparison of the assemblages recovered from Sites 747, 748, and 749 reveals that, even in the early Eocene, diversity was higher at Site 747 than at Sites 748 and 749. Discoasters were also more common and more diversified at Site 747 than at Sites 748 and 749 , where the ratio of Chiasmolithus to discoasters (Bukry, 1973) is higher than at the former site. It has been shown above (Fig. 6) that there is also some diachrony in the LOs and HOs of a number of index species between the northern and southern sites. This differentiation between Site 747 on the one hand and Sites 748 and 749 on the other may be explained in several ways. As the three sites were at about the same water depth during the Paleogene (Mackensen, this volume), differences between depositional environments may be ruled out. Site 747 was located close to a coast during the Paleogene, whereas Sites 748 and 749 were fully oceanic (Schlich, Wise, et al., 1989, pp. 7-23). Thus, a greater abundance of calcareous nannofloras at Site 747 may reflect a coastal effect.

Diversity differences between Site 747 and Sites 748 and 749 may also result from latitudinal difference. This latitudinal difference $\left(4^{\circ}\right)$ is, however, quite small and may be insufficient. The possibility remains that differences in calcareous nannoplankton diversity between sites are related to differences in water masses, Site 747 being located in a warmer water mass than Sites 748 and 749 . This conjecture cannot be tested at this time because no middle Eocene sediments were recovered from Site 747 , thus precluding a thorough comparison between sites. However, a study of the Miocene assemblages from Sites 747 and 751 , which are separated by only $3^{\circ}$ latitude, shows that differences between these two sites reflect different water masses (Beaufort, 1991).

\section{ACKNOWLEDGMENTS}

I am thankful to the master and crew of the JOIDES RESOLUTION and ODP technical staff for their cooperation and assistance on board ship. Discussions with W. A. Berggren, F. Heider, and $\mathrm{H}$. Inokuchi helped in clarifying problems associated with the bio- and magnetostratigraphic correlations. Constructive reviews of this manuscript by D. Bukry, K. Perch-Nielsen, J. Steinmetz, E. Thomas and P. Valentine are gratefully acknowledged.

\section{TAXONOMIC INDEX}

Biantholithus sparsus Bramlette and Martini, 1964

Biscutum constans (Gorka, 1957) Black in Black and Barnes, 1959 Chiasmolithus altus Bukry and Percival, 1971

C. bidens (Bramlette and Sullivan, 1961) Hay and Mohler, 1967

C. consuetus (Bramlette and Sullivan, 1961) Hay and Mohler, 1967

C. danicus (Brotzen, 1959) Hay and Mohler, 1967

C. eograndis Perch-Nielsen, 1971

C. expansus (Bramlette and Sullivan, 1961) Gartner, 1970

C. grandis (Bramlette and Riedel, 1954) Radomski, 1968

C. oamaruensis (Deflandre, 1954) Hay, Mohler, and Wade, 1966
C. solitus (Bramlette and Sullivan, 1961) Locker, 1968

Chiphragmalithus Bramlette and Sullivan, 1961

Clausicoccus subdistichus (Roth and Hay in Hay et al., 1967) Prins, 1979

Coccolithus crassus Bramlette and Sullivan, 1961

C. pelagicus (Wallich, 1877) Schiller, 1930

Cruciplacolithus edwardsii Romein, 1979

C. primus Perch-Nielsen, 1977

C. tenuis (Stradner, 1961) Hay and Mohler in Hay et al., 1967

Discoaster barbadiensis Tan, 1927

D. binodosus Martini, 1958

D. cruciformis Martini, 1958

D. diastypus Bramlette and Sullivan, 1961

D. elegans Bramlette and Sullivan, 1961

D. falcatus Bramlette and Sullivan, 1961

D. kuepperi Stradner, 1959

D. lodoensis Bramlette and Riedel, 1954

D. mohleri Bukry and Percival, 1971

D. multiradiatus Bramlette and Riedel, 1954

D. nobilis Martini, 1971

D. pacificus Haq, 1969

D. saipanensis Bramlette and Riedel, 1954

D. sublodoensis Bramlette and Sullivan, 1961

D. tanii Bramlette and Riedel, 1954

D. tanii nodifer Bramlette and Riedel, 1954

Ellipsolithus bollii Perch-Nielsen, 1977

E. distichus (Bramlette and Sullivan, 1961) Sullivan, 1964

E. lajollaensis Bukry and Percival, 1971

E. macellus (Bramlette and Sullivan, 1961) Sullivan, 1964

Ericsonia formosa (Kamptner, 1963) Haq, 1971

E. subpertusa Hay and Mohler, 1967

Fasciculithus tympaniformis Hay and Mohler in Hay et al., 1967

Helicosphaera lophota Bramlette and Sullivan, 1961

Heliolithus cantabriae Perch-Nielsen, 1971

$H$. kleinpellii Sullivan, 1964

$H$. riedelii Bramlette and Sullivan, 1961

Hornibrookina australis Edwards and Perch-Nielsen, 1975

H. teuriensis Edwards, 1973

Isthmolithus recurvus Deflandre, 1954

Lanternithus minutus Stradner, 1962

Lophodolithus nascens Bramlette and Sullivan, 1961

Markalius inversus (Deflandre in Deflandre and Fert, 1954) Bramlette and Martini, 1964

Nannotetrina fulgens (Stradner, 1960) Achutan and Stradner, 1969

Neochiastozygus cearae Perch-Nielsen, 1977

N. distentus (Bramlette and Sullivan, 1961) Perch-Nielsen, 1971

N. junctus (Bramlette and Sullivan, 1961) Perch-Nielsen, 1971

N. saepes Perch-Nielsen, 1971

Neococcolithes dubius (Deflandre, 1954) Black, 1967

Pedinocyclus larvalis (Bukry and Bramlette, 1969) Loeblich and Tappan, 1973

Placozygus sigmoides (Bramlette and Sullivan, 1961) Romein, 1979

Pontophaera fimbriata Bramlette and Sullivan, 1961

Prinsius bisulcus (Stradner, 1963) Hay and Mohler, 1967

P. martinii (Perch-Nielsen, 1969) Haq, 1971

Pseudotriquetrorhabdulus inversus (Bukry and Bramlette, 1969) Wise in Wise and Constans, 1976

Reticulofenestra bisecta (Hay, Mohler, and Wade, 1966)

$R$. dictyoda (Deflandre in Deflandre and Fert, 1954) Stradner in Stradner and Edwards, 1968

R. floridana (Roth and Hay in Hay et al., 1967)

$R$. hampdenensis Edwards, 1973

$R$. hesslandii Haq, 1966

$R$. hillae Bukry and Percival, 1971

$R$. oamaruensis (Deflandre in Deflandre and Fert, 1954) Stradner in Haq, 1968

R. reticulata (Gartner and Smith, 1967) Roth and Thierstein, 1972

$R$. samodurovii (Hay, Mohler, and Wade, 1966) Roth, 1970

Rhabdosphaera tenuis Bramlette and Sullivan, 1961

Scampanella Forchheimer and Stradner, 1973 emend. Perch-Nielsen and Franz, 1977

Semihololithus kerabyi Perch-Nielsen, 1971

Sphenolithus moriformis (Brönnimann and Stradner, 1960) Bramlette and Wilcoxon, 1967 
S. primus Perch-Nielsen, 1971

$S$. radians Deflandre in Grassé, 1952

Thoracosphaera Kamptner, 1927

Toweius callosus Perch-Nielsen, 1971

T. eminens (Bramlette and Sullivan, 1961) Perch-Nielsen, 1971

T. gammation (Bramlette and Sullivan) Romein, 1979

T. magnicrassus (Bukry, 1971) Romein, 1979

T. pertusus (Sullivan, 1965) Romein, 1979

T. tovae Perch-Nielsen, 1971

Zygrhablithus bijugatus (Deflandre in Deflandre and Fert, 1954) Deflandre, 1959

\section{REFERENCES}

Aubry, M.-P., 1983. Biostratigraphie du Paléogène épicontinental de l'Europe du Nord-Ouest. Etude fondée sur les nannofossiles calcaires. Doc. Lab. Geol. Lyon, No. 89.

1991. Sequence stratigraphy: eustasy or tectonic imprint? J. Geophys. Res., 96:6641-6679.

Aubry, M.-P., and Berggren, W. A., 1989. Age of the upper volcaniclastic debris flow at Site 747: a special study. In Schlich, R., Wise, S. W., Jr., et al., Proc. ODP, Init. Repts., 120: College Station, TX (Ocean Drilling Program), 57-72.

Aubry, M.-P., Berggren, W. A., Kent, D. V., Flynn, J. J., Klitgord, K. D., Obradovich, J. D., and Prothero, D. R., 1988. Paleogene geochronology: an integrated approach. Paleoceanography, $3: 707-742$.

Beaufort, L., in press. A seventeen million years long record of Miocene water mass movements in the southern Indian Ocean inferred from calcareous nannofossil distribution. Micropaleontology.

Berggren, W. A., Kent, D. V., and Flynn, J. J., 1985. Jurassic to Paleogene: Part 2. Paleogene geochronology and chronostratigraphy. In Snelling, N. J. (Ed.), The Chronology of the Geological Record. Geol. Soc. London Mem., 10:141 195.

Bukry, D., 1973. Low-latitude coccolith biostratigraphic zonation. In Edgar, N. T., Saunders, J. B., et al., Init. Repts. DSDP, 15: Washington (U.S. Govt. Printing Office), 685-703.

1975. Coccolith and silicoflagellate stratigraphy, northwestern Pacific Ocean, Deep Sea Drilling Project Leg 32. In Larson, R. L., Moberly, R., et al., Init. Repts. DSDP, 32: Washington (U.S. Govt. Printing Office), 677-701.

Bukry, D., and Snavely, P. D., Jr., 1988. Coccolith zonation for Paleogene strata in the Oregon Coast Range. In Filewicz, M. V., and Squires, R. L. (Eds.), Paleogene Stratigraphy, West Coast of
North America, Soc. Econ. Paleontol. Mineral., Pacific section, West Coast Paleogene Symp., 58:251-263.

Edwards, A. R., and Perch-Nielsen, K., 1975. Calcareous nannofossils from the southern Southwest Pacific, DSDP Leg 29. In Kennett, J. P., Houtz, R. E., et al., Init. Repts. DSDP, 29: Washington (U.S. Govt. Printing Office), 469-539.

Kennett, J. P., 1978. The development of planktonic biogeography in the Southern Ocean during the Cenozoic. Mar. Micropaleontol., 3:301-345.

Martini, E., 1971. Standard Tertiary and Quaternary calcareous nannoplankton zonation. In Farinacci, A. (Ed.), Proc. 2nd Planktonic Conf. Roma: Rome (Ed. Technoscienza), 2:739-785.

Okada, H., and Bukry, D., 1980. Supplementary modification and introduction of code numbers to the Low latitude coccolith biostratigraphic zonation (Bukry, 1973; 1975). Mar. Micropaleontol., 5:321-325.

Perch-Nielsen, K., 1977. Albian to Pleistocene calcareous nannofossils from the western South Atlantic. In Perch-Nielsen, K., Supko, P. R., et al., Init. Repts. DSDP, 39: Washington (U.S. Govt. Printing Office), 699-823. 1985. Cenozoic calcareous nannofossils. In Bolli, H. M., Saunders, J. B., and Perch-Nielsen, K. (Eds.), Plankton Stratigraphy: Cambridge (Cambridge Univ. Press), 427-554.

Schlich, R., Wise, S. W., Jr., et al., 1989. Proc. ODP, Init. Repts., 120: College Station, TX (Ocean Drilling Program).

Shipboard Scientific Party, 1988a. Explanatory notes. In Barker, P. F., Kennett, J. P., et al., Proc. ODP, Init. Repts., 113: College Station, TX (Ocean Drilling Program), 13-32. 1988b. Explanatory notes. In Ciesielski, P. F., Kristoffersen, Y., et al., Proc. ODP, Init. Repts., 114: College Station, TX (Ocean Drilling Program), 3-22.

Wise, S. W., Jr., 1983. Mesozoic and Cenozoic calcareous nannofossils recovered by Deep Sea Drilling Project Leg 71 in the Falkland Plateau region, Southwest Atlantic Ocean. In Ludwig, W. J., Krasheninnikov, V. A., et al., Init. Repts. DSDP, 71, Pt. 2: Washington (U.S. Govt. Printing Office), 481-550.

Wise, S. W., Jr., and Wind, F. H., 1976. Mesozoic and Cenozoic calcareous nannofossils recovered by DSDP Leg 36 drilling on the Falkland Plateau, Southwest Atlantic sector of the Southern Ocean. In Barker, P. F., Dalziel, I.W.D., et al., Init. Repts. DSDP, 36: Washington (U.S. Govt. Printing Office), 269-492.

Date of initial receipt: 18 June 1990

Date of acceptance: 2 January 1991

Ms 120B-149 